\title{
PENGEMBANGAN MEDIA PENGUKUR VOLUME BENDA BERBENTUK TIDAK TERATUR BERBAHAN WADAH MINUMAN BEKAS PADA MASA "PTMT"
}

\author{
RR. INDAH WAHJU RATNAWATI \\ SMP Negeri 2 Kalitidu, Bojonegoro, Jawa Timur \\ Email : rrindahratnawati@gmail.com
}

\begin{abstract}
ABSTRAK
Penelitian ini bertujuan untuk menghasilkan produk berupa media pengukur volume benda yang berbentuk tidak teratur, berbahan wadah minuman bekas. Jenis media yang dikembangkan berupa alat bantu praktik. Penelitian ini termasuk penelitian pengembangan yang dikenal dengan istilah Research and Development. Pada masa pembelajaran dengan tatap muka terbatas (PTMT) proses pembelajaran harus di rancang seefektif mungkin, karena siswa belajar di sekolah hanya sekitar 4 jam, tanpa istirahat. Keberadaan alat bantu praktik sangat membantu pemahaman siswa terhadap konsep yang dijelaskan guru, namun tidak semua sekolah memiliki peralatan laboratorium yang sebanding dengan jumlah siswa. Untuk mengatasi masalah tersebut diberikan solusi mengembangkan alat bantu praktik berbahan wadah minuman bekas pada pengukuran volume benda berbentuk tidak teratur. Sebelum alat bantu praktik diuji cobakan, dilakukan validasi oleh ahli materi dan ahli materi. Hasil rata-rata dari kedua ahli validasi . diperoleh scor 97,05\% dengan kategori sangat layak. Uji coba media meliputi uji terbatas yang terdiri dari 12 siswa kelas VII/B dan uji luas yang dilaksanakan pada seluruh siswa kelas VII/B sejumlah 32 siswa. Hasil uji terbatas diperoleh rata-rata 98,3\%, dan pada uji luas diperoleh rata-rata 99\% dengan predikat sangat layak juga. Setelah dilakukan uji coba siswa diberikan seperangkat alat tes berupa soal yang berkaitan dengan materi pengukuran volume benda yang bentuknya tidak teratur. Hasil test yang diselesaikan oleh siswa setelah menggunakan media yang dikembangkan, siswa yang memperoleh nilai diatas KKM adalah 96\%, hal ini menunjukkan bahwa media yang dikembangkan layak digunakan dan dapat membantu pemahaman siswa dalam mempelajari konsep pengukuran volume benda yang berbentuk tidak teratur.
\end{abstract}

Kata kunci: Pengukuran Volume, Benda berbentuk tidak teratur, wadah minuman bekas.

\section{ABSTRACT}

This study aims to produce a product in the form of a medium for measuring the volume of irregularly shaped objects, made from used drink containers. The type of media developed is in the form of practical aids. This research includes development research known as Research and Development. During the limited face-to-face learning period (PTMT) the learning process must be designed as effectively as possible, because students study at school for only about 4 hours, without rest. The existence of practical aids is very helpful for students' understanding of the concepts explained by the teacher, but not all schools have laboratory equipment that is proportional to the number of students. To overcome this problem, a solution is given to develop a practical tool made from used drink containers for measuring the volume of irregularly shaped objects. Before the practical aids were tested, they were validated by material experts and material experts. The average results of the two validation experts. obtained a score of $97.05 \%$ with a very decent category. The media trial included a limited test consisting of 12 students of class VII/B and a broad test which was carried out on all students of class VII/B of 32 students. The results of the limited test obtained an average of $98.3 \%$, and in the broad test an average of $99 \%$ was obtained with a very decent predicate as well. After the trial, the students were given a set of test tools in the form of questions related to the material for measuring the volume of objects with irregular shapes. The results of the tests completed by students after using the developed media, students who scored above the KKM were 96\%, this indicates that the developed media is feasible to use and can help students understand the concept of measuring the volume of irregularly shaped objects. 
Keywords: Volume measurement, irregularly shaped objects, used drink containers.

\section{PENDAHULUAN}

Masa Pandemi covid-19 yang berlangsung kurang-lebih 2 tahun mengharuskan siswa belajar dari rumah. Pembukaan sekolah dengan pembelajaran tatap muka disambut antusias oleh warga sekolah, orang tua siswa ataupun masyarakat luas. Namun demikian mengatur siswa SMP untuk menerapkan protokol kesehatan dengan menggunakan masker yang baik dan benar tidaklah mudah. Sedangkan pembelajaran tatap muka di sekolah harus mengikuti arahan dari Kementerian Pendidikan, dengan penerapan protokol kesehatan yang ketat. Protokol kesehatan yang harus dilaksanakan antara lain pembatasan jumlah siswa yang diijinkan masuk sekolah, pembatasan jam belajar di sekolah, serta tidak ada jam istirahat. Dalam satu kelas hanya boleh diisi $50 \%$ dari jumlah siswa seluruhnya, dan pembelajaran disekolah hanya berlangsung kurang-lebih 4 jam saja. Hal tersebut dikenal dengan istilah pembelajaran tatap muka terbatas (PTMT).

Untuk memenuhi anjuran PTMT dari Kementerian Pendidikan, sekolah tempat peneliti bekerja dilakukan penerapan kebijakan antara lain: tidak ada jam istirahat, masingmasing siswa membawa minum sendiri dan selesai sekolah harus langsung pulang. Hal tersebut bertolak belakang dengan kebiasaan sebelum pandemic. Siswa memiliki waktu bermain saat jam istirahat, bisa jajan dikantin untuk makan-minum sebagai pengganti energi yang hilang. Siswa juga bisa duduk bersebelahan dengan kawan sebangku tanpa ada aturan pembatasan jarak. Saat mereka harus kembali ke sekolah pada masa PTMT ini, kebiasaan tersebut belum bisa ditinggalkan $100 \%$. Adanya berbagai aturan tersebut menjadikan siswa kurang bersemangat saat mengikuti pelajaran. Hal itu terlihat saat pembelajaran IPA materi pengukuran volume benda yang berbentuk tidak teratur. Tidak adanya kawan sebangku yang bisa diajak berbincang-bincang untuk menghilangkan kejenuhan, tidak adanya jam istirahat, ditambah dengan ketiadaan alat laboratorium untuk menunjang kegiatan praktikum menjadikan siswa kurang antusias dalam mengikuti pembelajaran IPA. Pada saat belajar materi benda yang berbentuk tidak teratur, kebanyakan dari siswa hanya duduk, mendengarkan penjelasan guru, mengerjakan soal dan mencatat hal-hal yang dianggap penting. Tidak jarang siswa terlihat enggan dan mengantuk saat pembelajaran berlangsung. Hal ini berdampak pada penurunan hasil belajar siswa, yang ditandai dengan banyak siswa yang memperoleh nilai dibawah KKM. Kondisi ini tidak sesuai dengan harapan bahwa adanya pembelajaran tatap muka akan menjadikan siswa lebih bersemangat dalam menuntut ilmu, sehingga hasil belajar akan meningkatkan.

Adanya kesenjangan antara harapan dan kenyataan tersebut, maka peneliti menawarkan solusi dalam mempelajari materi menghitung volume benda berbentuk tidak teratur, digunakan alat bantu praktik yang dikembangkan oleh peneliti. Alat bantu praktik tersebut, terbuat dari wadah minuman bekas berbahan plastic. Alat bantu praktik yang peneliti kembangkan, dapat juga berfunsi sebagai alternatif sekolah lain yang peralatan laboratoriumnya tidak sebanding dengan jumlah siswa. Selain itu juga berfungsi sebagai alternatif mengantisipasi kecerobohan siswa saat melaksanakan praktikum. Apabila ada siswa yang ceroboh, tanpa sengaja menjatuhkan alat praktik, maka alat praktik tersebut tidak akan pecah. Bahan untuk membuat alat bantu praktikum ini tidak perlu dibeli, cukup dicari ditempat sampah atau dipengepul barang-barang bekas. Keselamatan kerja saat praktikum di laboratorium menjadi lebih terjamin. Bahan plastic merupakan bahan yang tembus pandang, sehingga perubahan volume akibat benda yang dimasukkan kedalam media alat ukur akan terlihat jelas. Dengan demikian memudahkan dalam pengamatan ataupun pengunaannya.

Menurut peneliti keberhasilan pembelajaran IPA sangat ditunjang dengan adanya kegiatan praktik di laboratorium. Hal ini sejalan dengan pemikiran Sufiyanto (2021) dengan praktik, siswa akan lebih mudah memahami materi yang disampaikan oleh guru, sehingga dapat meningkatkan hasil belajarnya. Praktik dilakukan ditempat khusus yaitu laboratorium yang didalamnya terdapat alat-alat praktik. Adanya laboratorium beserta alat pratiknya ini sangat 
dibutuhkan dalam suatu satuan pendidikan. Demikian juga menurut Darmayanti, Wijaya \& Hanifaturrohmah. (2020) yang mengatakan bahwa pembelajaran IPA tidak bisa lepas dari kegiatan praktikum. Untuk itu keberadaan alat bantu praktikum mutlak diperlukan dalam membekali siswa mengenal kegiatan ilmiah. Kebanyakan peralatan laboratorium terbuat dari kaca yang rawan pecah, bahkan banyak pula sekolah-sekolah yang tidak memiliki alat praktik laboratorium. Untuk itu perlu dicarikan solusi pengadaan alat-alat laboratorium yang tidak mudah pecah apabila terjatuh. Fenomena itulah yang mendorong peneliti untuk melakukan penelitian pengembangan media alat bantu praktik pengukur volume benda yang berbentuk tidak teratur dari wadah bekas berbahan plastic pada masa PTMT ini.

\section{METODE PENELITIAN}

Penelitian ini adalah penelitian pengembangan yang dikenal dengan istilah Research And Development (R\&D). Tujuan penelitian pengembangan ini adalah untuk mengembangkan media alat bantu praktikum, Media ini nantinya dapat digunakan untuk mempelajari volume benda yang berbentuk tidak teratur. Dengan demikian ketiadaan peralatan laboratorium bukan lagi menjadi kendala siswa untuk belajar secara real melalui kegiatan praktikum di laboratorium. Hal tersebut dapat menghapus anggapan siswa bahwa matapelajaran IPA hanya berupa teoritis saja,

Penelitian ini mengacu pada model pengembangan 4D yang dikembangkan oleh Thiagarajan. Model ini terdiri dari empat tahapan yaitu define, design, development dan disseminate (Natasya \& Izati, 2020). Tahap define yang lebih sering dikenal dengan istilah analisis kebutuhan, dilakukan dengan menganalisis kurikulum, media pembelajaran serta analisis peserta didik. Analisis kurikulum dilakukan untuk mengetahui kompetensi dasar apa yang akan dikembangkan dalam suatu kurikulum. Analisis media dimaksudkan untuk menentukan media apa yang dibutuhkan disekolah tersebut. Analisis peserta didik harus dilakukan karena semua proses pembelajaran harus disesuaikan dengan karakteristik peserta didik.

Tahap design, pada tahap ini dilakukan rancangan purwarupa media yang akan dikembangkan. Selanjutnya adalah tahap development (pengembangan). Setelah media berhasil dibuat, kegiatan dilanjutkan dengan memvalidasi kelayakan produk, setelah itu dilakukan uji coba terbatas. Jika ada saran dari validator maka dilakukan revisi dan perbaikan produk. Pada Tahap berikutnya dilakukan disseminasi (penyebar luasan). Karena media yang dikembangkan adalah alat bantu praktikum maka pada tahap disseminasi ini media tersebut disebarkan untuk digunakan pada pembelajaran yang lebih luas.

Subjek uji coba penelitian ini adalah siswa kelas VII/B SMPN 2 Kalitidu sebanyak 32 siswa. Waktu penelitian minggu ketiga bulan November 2021. Pengumpulan data dilakukan dengan angket yang disebarkan melalui google form, uji kepractisan dan uji kelayakan, Uji kepraktisan meliputi kepraktisan dalam penyimpanan, perawatan alat maupun kemudahan dalam pengoperasionalan alat. Instrument yang digunakan dalam penelitian ini adalah: angket yang disebarkan melalui google form kepada siswa, angket kepraktisan dan lembar validasi yang diberikan pada validator. Survey dengan google form digunakan untuk mengetahui kompetensi dasar apa yang membutuhkan pengembangan media. Lembar validasi digunakan untuk mengetahui kelayakan media. Untuk mengetahui kepractisan media digunakan angket kepraktisan.Validator dalam penelitian ini terdiri dari ahli materi dan ahli media. Teknik analisis data mengacu kepada metode yang dikembangkan oleh Gable yaitu Method of summated ratings (izati,2021). Untuk memperoleh persentase kelayakan, maka rumus yang digunakan adalah:

$$
\text { Persentase }=\frac{\text { Jumtah } \text { skor hasil validasi }}{\text { Skor tertinggi }} \times 100 \%
$$

Dari hasil perhitungan tersebut, kriteria interpretasinya adalah sebagai berikut: 
Tabel: 1. persentase kelayakan media

Persentase kelayakan media

\begin{tabular}{cc}
\hline Penilaian & Kriteria Interpretasi \\
\hline $0 \%-20 \%$ & Sangat Tidak Layak \\
$21 \%-40 \%$ & Tidak Layak \\
$41 \%-60 \%$ & Cukup Layak \\
$61 \%-80 \%$ & Layak \\
$81 \%-100 \%$ & Sangat Layak \\
\hline
\end{tabular}

(Riduwan,2013:15 dalam (Fatiris, 2017:8))

\section{HASIL DAN PEMBAHASAN}

Hasil utama dalam penelitian ini adalah media alat bantu praktikum untuk mengukur volume benda yang berbentuk tidak teratur. Media ini berbentuk gelas ukur berbahan plastic dari wadah minuman bekas. Validasi produk dilakukan oleh ahli materi dan ahli media. Ahli materi akan menguji kesesuaian media dengan Kompetesi dasar, tujuan pembelajaran dan materi pelajaran yang disampaikan. Ahli media akan menguji kelayakan media dari manfaat media, desain media dan kepraktisan media. Uji coba dilaksanakan pada bulan November minggu ketiga 2021.

Berikut adalah deskripsi tahapan perkembangan produk.

a. Tahap Define

Tahap define disebut juga tahap analisis kebutuhan. Pada tahap ini dilakukan pendefinisikan syarat-syarat pengembangan. Sehingga didapatkan informasi mengenai kurikulum yang dipakai, media yang diperlukan serta Kompetensi dasar yang akan dikembangkan. Hal tersebut dilakukan dengan memberikan angket yang harus diisi siswa melalui google form. Rumus yang digunakan adalah rumus persentase dari Sugiono, yang secara matematis ditulis sebagai berikut:

Persentase $=$ jumlah siswa yang menyatakan guru menggunakan media $\times 100 \%$ Jumlah siswa seluruhnya

(Sugiono dalam Ratnawati, 2021)

Dari hasil survey didapatkan bahwa SMPN 2 kalitidu tempat penelitian ini dilakukan menggunakan Kurikulum 2013. Pada siswa kelas VII/B sejumlah 32 diberikan angket yang di sebarkan melalui google form. Angket tersebut berkaitan dengan Kompetensi Dasar pada materi pengukuran volume benda. Angket yang berisikan pertanyaan apakah pengukuran volume benda tidak teratur dapat dilakukan dengan menggunakan rumus, didapatkan data: $90 \%$ menyatakan tidak bisa melakukan dan $10 \%$ menyatakan bisa, namun sulit dilakukan. Selanjutnya dilakukan analisis media untuk mengetahui media apa yang digunakan untuk mengukur volume benda pada pembelajaran sebelumnya. Hasil analisis diperoleh data sebagai berikut: $40 \%$ menyatakan guru tidak pernah menggunakan media pembelajaran, 60\% menyatakan bahwa guru menggunakan media pembelajaran dengan metode demonstrasi, namun medianya kecil dan tidak bisa terlihat dengan jelas dari tempat duduk siswa bagian belakang. Untuk pertanyaan apakah dari hasil membaca buku dan penjelasan guru siswa memahami konsep cara pengukuran benda yang bentuknya tidak teratur, diperoleh data $65 \%$ menyatakan tidak memahami, $25 \%$ menyatakan sulit memahami dan $10 \%$ menyatakan mudah memahami. Hasil survey awal tersebut jika ditampilkan dalam diagram adalah sebagai berikut:
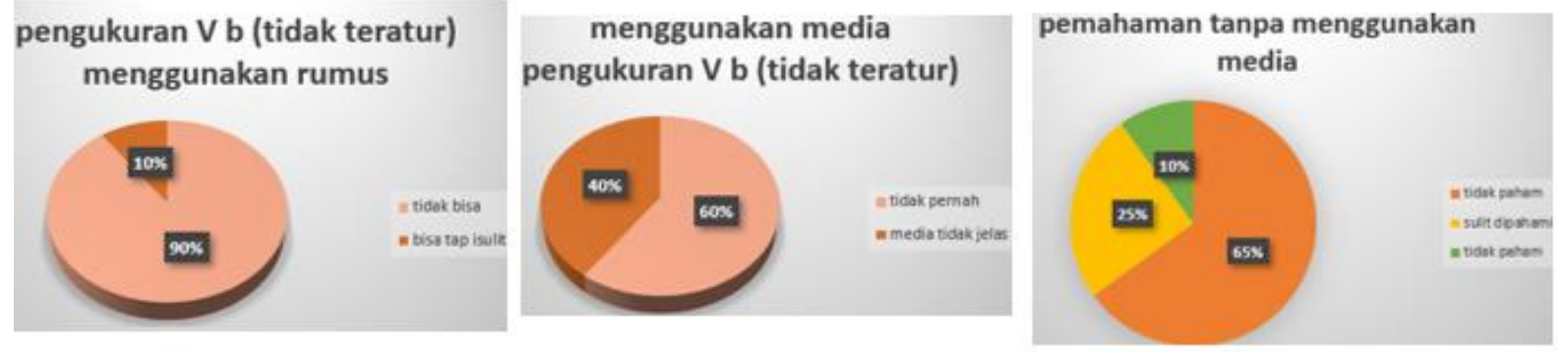

Gambar 1. Survey awal 
Dari diagram diatas dapat disimpulkan bahwa siswa tidak bisa menghitung volume benda yang bentuknya tidak teratur dengan mengunakan rumus. Siswa sulit memahami konsep materi benda tidak teratur bentuknya dari membaca buku dan penjelasan guru tanpa menggunakan media. Pembelajaran sebelumnya guru menggunakan media untuk mengukur volume benda tidak teratur, tetapi siswa tidak jelas karena hanya demontrasi dan alat praktik terlalu kecil. Siswa tidak diminta untuk melaksanakan praktikum dlam kelompok kecil, hal tersebut dikarenakan alat bantu praktikum sebagai media pengukur volume benda tidak tertur tidak sebanding dengan jumlah siswa. Dari hasil survey awal dapat diketahui bahwa pengembangan media alat bantu praktikum sangat diperlukan siswa untuk meningkatkan pemahaman dan hasil belajarnya.

b. Tahap Design

Pada tahap ini dirancang purwarupa media pembelajaran alat bantu praktik untuk mempelajari volume benda yang bentuknya tidak teratur. Adapun bahan yang diperlukan antara lain spidol, kertas untuk membuat ukuran skala, gelas minuman bekas , gelas takaran dan slotip bening. Dengan menggunakan gelas takaran dibuat skala mulai $10 \mathrm{ml}, 20 \mathrm{ml}$ sampai $200 \mathrm{ml}$ caranya dengan menempelkan kertas pada gelas minuman bekas, setelah itu air dituangkan 10ml. Setiap 10ml kertas diberikan tanda “_.", dengan menggunakan spidol. Pada tiap setrip (-) diberikan angka mulai $10 \mathrm{ml}, 20 \mathrm{ml}$, dan setrusnya sampai $200 \mathrm{ml}$, sesuai urutan dari yang terkecil ke besar.

c. Tahap development

Pada tahap ini bertujuan menghasilkan media alat bantu praktik pengukur volume benda yang bentuknya tidak teratur. Validasi dilakukan oleh validator melalui lembar validasi dan angket kepraktisan. Validator terdiri dari ahli materi dan ahli media. Aspek penilaian dari ahli materi terdiri dari kesesuaian media dengan kompetensi dasar, kesesuaian media dengan tujuan pembelajaran dan kesesuaian media dengan materi pelajaran. Hasil rekapitulasi validasi dari ahli materi diperoleh persentase rata-rata 97,8\%, sehingga dapat disimpulkan media pembelajaran alat bantu praktikum pengukur volume benda berbentuk tidak teratur yang dikembangkan menunjukkan kriteria yang sangat layak dari segi kesesuaian materi. Sedangkan hasil validasi media diperoleh persentase rata-rata 96,3\%, sehingga dapat disimpulkan media yang dikembangkan menunujukkan kriteria sangat layak, dan saran perbaikan dari ahli media dipakai sebagai acuan perbaikan media yang dikembangkan oleh peneliti. Pada pemilihan wadah bekas minuman dipilih yang agak besar, sehingga dapat digunakan untuk mengukur volume benda sampai $1000 \mathrm{ml}$. Untuk skala tiap kenaikan $10 \mathrm{ml}$ diberikan tanda “_“, walaupun tidak ditulis angkanya dan tidak perlu ditulis dalam kertas, cukup ditulis pada wadahnya Hal tersebut dimaksudkan agar tidak menganggu pemngamatan saat praktikum dilakukan. Perlu dibuat alat praktik dalam berbagai ukuran, apabila bendanya kecil digunkan alat bantu praktik yang kecil, demikian sebaliknya, sehingga hasil pengukuran menjadi lebih teliti.

Perbandingan media sebelum revisi dan sesudah revisi disajikan dalam gambar berikut:

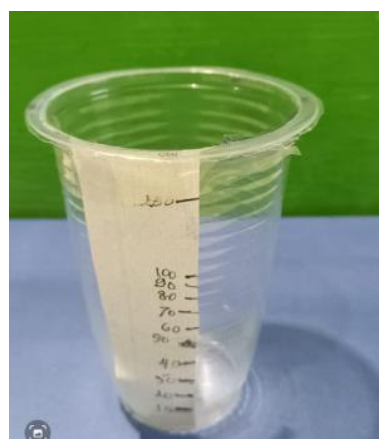

Gambar 2. Media sebelum revisi 


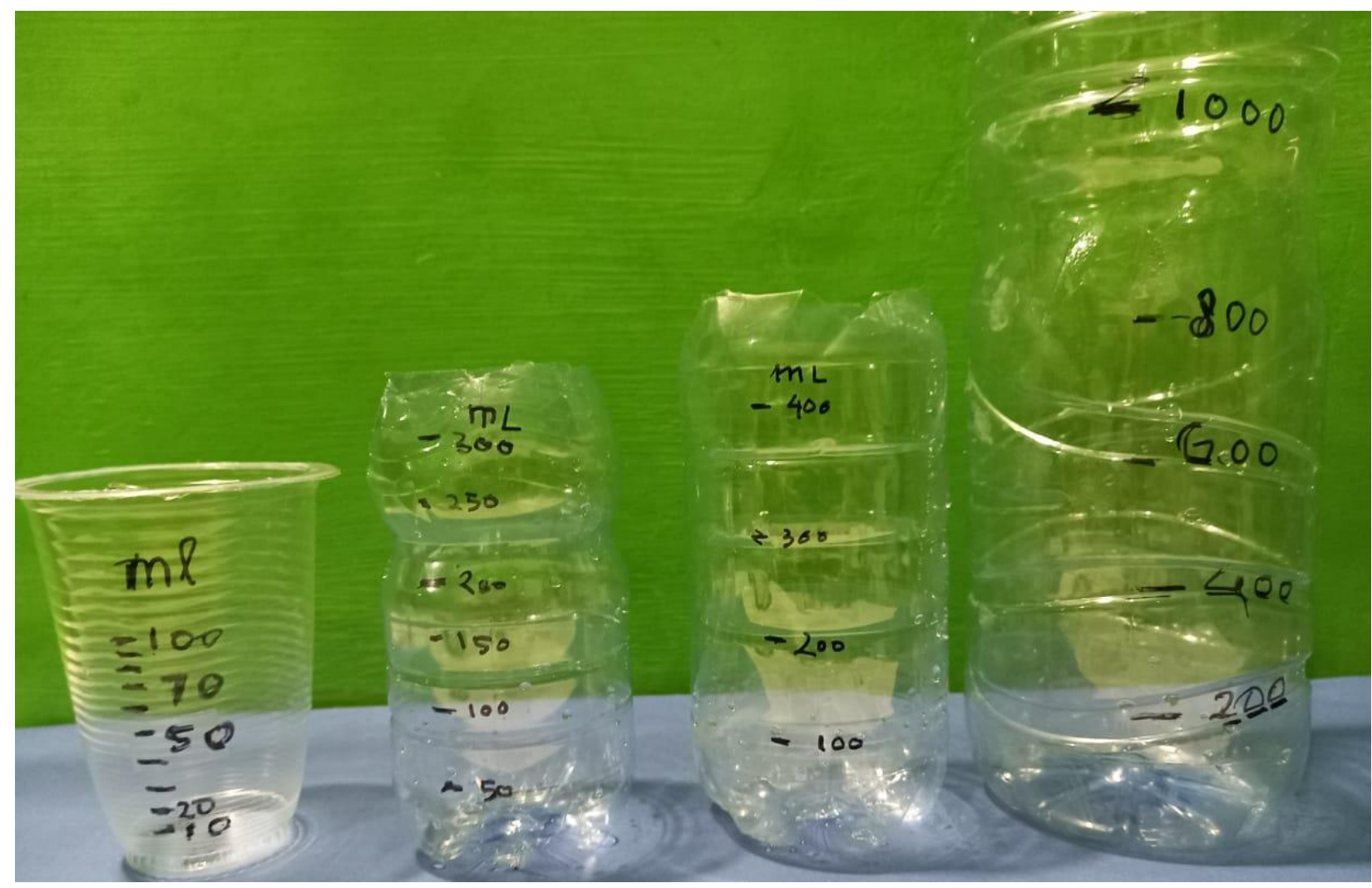

Gambar 3. Media sesudah revisi

Rekapitulasi hasil validasi secara keseluruhan baik dari ahli materi maupun dari ahli media disajikan dalam table berikut:

Tabel 2. rekapitulasi hasil validasi.

\begin{tabular}{|l|l|l|l|}
\hline No. & validator & hasil & predikat \\
\hline 1. & Ahli materi & $97,8 \%$ & Sangat layak \\
\hline 2. & Ahli media & $96,3 \%$ & Sangat layak \\
\hline 3 & Rata-rata presentasi & $97,05 \%$ & Sangat layak \\
\hline
\end{tabular}

Berdasarkan Tabel di atas, dapat dijelaskan bahwa hasil keseluruhan validasi diperoleh rata-rata persentase $97,05 \%$ dengan predikat sangat layak, dan dapat dilanjutkan untuk uji coba terbatas. Uji coba terbatas dilakukan pada bulan November 2021 di kelas VII/B SMP Negeri 2 Kalitidu dengan jumlah 12 siswa yang terbagi dalam 3 kelompok. Peneliti memberikan lembar angket respon kepraktisan kepada siswa yang mencakup 10 pernyataan. Setelah dianalisi diperoleh rata-rata persentase 98,3\% dengan kriteria sangat layak. Sehingga dapat disimpulkan bahwa media yang dikembangkan melalui uji coba terbatas sangat layak digunakan dan dapat dilanjutkan pada tahap Disseminate

\section{d. Tahap Disseminate}

Pada tahap ini dilakukan uji luas dengan cara mengujikan media yang telah dikembangkan pada seluruh siswa dalam kelas VII/B yang berjumlah 32 siswa yang terbagi dalam 8kelompok kecil, 99\% menyatakan mudah memahami materi pengukuran volume benda berbentuk tidak teratur dengan menggunakan media yang telah dikembangka. $\mathrm{P}$ engunaanserta penyimpanannya sangat praktis dan cara membersihkan alat bantu pratikum ini pun sangat mudah. Evaluasi dengan menggunakan instrument tes menunjukkan ketuntasan klasiklal sebesar 96\%. Nilai tes terekam pada lembar penilaian harian siswa. Dari hasil validasi dan uji kelayakan dapat disimpulkan bahwa alat bantu praktikum pengukur volume benda berbentuk tidak teratur dari wadah bekas ini dapat diterima pengguna dengan baik dan layak digunakan dalam pembelajaran. 
Hasil penelitian pengembangan tersebut sesuai dengan pendapat Anjarwati dan Kardani (2021) bahwa benda-banda disekitar kita dapat dikembangkan menjadi suatu media pembelajaran karena memiki beberapa keunggulan biaya produksi relative murah dan bahan mudah didapat. Jadi peralatan laboratorium untuk kegiatan praktikum tidak harus yang mahal, tetapi dapat juga diganti dengan benda dari barang bekas namun memenuhi kriteria yang diinginkan. Hal serupa juga diungkapkan oleh Khoir, Witono \& Jariah (2021) pengembangan media berbahan dasar barang bekas jika dikemas dalam bentuk tampilan yang menarik maka mendapat respon sangat baik dari siswa dan layak digunakan untuk dalam proses pembelajaran. Masturoh, Sudarmi \& Noviandini (2019) juga mengatakan hal serupa bahwa penggunaan alat peraga sederhana dengan barang bekas disekitar sebagai media, terbukti dan berhasil membuat siswa paham terhadap suatu konsep.

\section{KESIMPULAN}

Media pembelajaran pengukur volume benda yang berbentuk tidak teratur dari wadah bekas ini dikembangkan dengan mengacu pada model pengembangan 4D yang meliputi define, design, development dan dessemenate. Dari survey awal siswa yang diminta mempelajari buku dan mendengarkan penjelasan guru tanpa menggunakan media dalam mempelajari pengukuran volume benda berbentuk tidak teratur hanya $10 \%$ yang paham, selebihnya kesulitan. Kesesuaian media dengan materi yang diajarkan sebesar 97,8\% dengan predikat sangat layak Validasi media dari ahli media 96,3\% dengan predikat sangat layak. Rata-rata presentase dari ahli materi dan ahli media sebesar $97,5 \%$ dengan predikat snagt layak juga. Pada uji terbatas diperoleh rata-rata persentasenya $98,3 \%$, dan pada uji luas diperoleh rata-rata presentase $99 \%$ dengan predikat sangat layak. Hasil test yang diselesaikan oleh siswa setelah menggunakan media persentase rata-rata ketuntasannya $96 \%$. Dengan demikian media alat bantu praktikum pengukur volume benda yang bentuknya tidak teratur dari wadah bekas layak digunakan dalam pembelajaran.

\section{DAFTAR PUSTAKA}

Anjarwati, S \& wardani, K. (2021). Pengembangan Media Pembelajaran Biologi melalui Pemanfaatan Barang Bekas di SMP Al-Islam Way Jepara. BIOEDUKASI Jurnal Pendidikan Biologi Universitas Muhammadiyah Metro.12(1). From https://ojs.fkip.ummetro.ac.id/index.php/biologi/article/view/3753/1673

Darmayanti, N. S., Wijaya, I. B., \& Hanifaturrohmah. (2020). Buku Panduan Praktikum IPA terpadu.

From

https://www.google.co.id/books/edition/Buku_Panduan_Praktikum_IPA_Terpadu_B erpe/I875DwAAQBAJ?hl=id\&gbpv=1\&dq=praktikum+ipa $+\&$ printsec=frontcover https://www.nap.edu/catalog/9853/how-people-learn-brain-mind-experience-andschool-expanded-edition.

Fatiris, N. (2017). Pengembangan Media Pembelajaran Kartu Uno pada Kompetensi Dasar Menjelaskan Sistem Kearsipan untuk Siswa Kelas X APK Di SMK Negeri 1 Surabaya. JPAP:Jurnal Administrasi Perkantoran, 5(2), 1-15. From https://sinta.kemdikbud.go.id/affiliations/detail?page $=860 \& \mathrm{id}=499 \& v i e w=$ document $\underline{\mathrm{S}}$

Jariah, A., Witono, H., \& Khoir, BN. (2021). Pengembangan Media Tiga Dimensi Kontekstual Berbahan Dasar Barang Bekas untuk Sisiwa Kelas IV SD. BIOCHEPHY: Journal of Science Education, 1(1), 7-12, from doi: http://dx.doi.org/10.21831/cp.v37i1.18787

Masturoh, RD., Sudarmi, M., \& Noviandini, D. (2019). Barang Bekas di Sekitarku (BARBEKU) Sebagai Alat Peraga Sederhana Untuk Meningkatkan Pemahaman Hukum III Newton. JUSES: Jurnal Sains dan Edukasi Sains, 2(1), 16 - 25, from doi: DOI: https://doi.org/10.24246/juses.v2i1p16-25

Mulyatiningsih, E. (2013). Metode Terapan Bidang Pendidikan. Bandung: Alfabeta. 
Natasya, J. \& Izzati, N. (2020)._Pengembangan Media Pembelajaran Animasi dengan Nuansa Kemaritiman Berbantuan Macromedia Flash 8 pada Materi Relasi Kelas VIII SMP. Jurnal Gantang.5(1), 87-93, from DOI: https://doi.org/10.31629/jg.v5i1.1948

Ratnawati, IW. (2021)._Pengembangan Modul Online Zat Aditif dengan Self Regulated Learning untuk Meningkatkan hasil Belajar Siswa. CENDEKIA: Jurnal Ilmu Pengetahuan. 1 (3), 193-202, from https://doi.org/10.51878/cendekia.v1i3.470

Sufiyanto, M. (2021)._Practicum Activities in the Field of Natural Science Learning in Elementary Schools as an Alternative to the Open Natural Science Laboratory. JUSTEK: Jurnal Sains \& Teknology. 4 (2), 11-20, from http://journal.ummat.ac.id/index.php/justek/article/view/5237/pdf 